\title{
Avian Diversity in Dilifekar Block, Arsi Mountains National Park, Ethiopia
}

\author{
Getachew Bantihun*, Shimekit Tadele, Abebe Ameha \\ Department of Applied Biology, School of Applied Natural Sciences, Adama Science and Technology University, Adama, Ethiopia
}

\section{Email address:}

geach.jon@gmail.com (G. Bantihun)

${ }^{*}$ Corresponding author

\section{To cite this article:}

Getachew Bantihun, Shimekit Tadele, Abebe Ameha. Avian Diversity in Dilifekar Block, Arsi Mountains National Park, Ethiopia. Advances in Bioscience and Bioengineering. Vol. 8, No. 1, 2020, pp. 6-11. doi: 10.11648/j.abb.20200801.12

Received: July 27, 2019; Accepted: August 30, 2019; Published: May 18, 2020

\begin{abstract}
This research was conducted at Dilfekar Block, Arsi Mountains National Park from August 2014-May 2015 during both wet and dry seasons with the aim to study diversity and taxonomy of bird species found in the block. Seven Transect lines of all with length $100 \mathrm{~m}$ and width $15 \mathrm{~m}$ were positioned in different representative microhabitat sites of the block. Data collection was carried out from the early morning to late morning and afternoon to late afternoon throughout the study periods. In this study, a total of 99 avian species under 36 families were identified from the Block. The largest and the least number of species of birds were recorded in transect $2(42.9 \%)$ and transect $3(7.2 \%)$ respectively. The variation in species abundance of the transects was statistically significant $\left(\chi^{2}=80.44, \mathrm{df}=6, \mathrm{p}<0.05\right)$. The Shannon diversity index $\left(\mathrm{H}^{\prime}\right)$ ranges from 1.9-3.6 of seven transects considered in the study area. Accordingly, the minimum index value was from transect 1 (1.9) and the maximum was from transect 2 (3.6). However, based on the Shannon diversity index value, the species of avian diversity among the transects was not statistically significant $\left(\chi^{2}=0.98, \mathrm{df}=6, \mathrm{p}>0.05\right)$. Evenness index $(\mathrm{E})$ for species of birds among transects ranged from 0.9-1.
\end{abstract}

Keywords: Abundance, Avian, Dilfekar, Diversity, Shannon Diversity Index, Species Richness

\section{Introduction}

Ethiopia is one of the world's rich biodiversity countries, which deserves awareness regionally and globally $[12,19]$. However, wildlife population in Ethiopia has diminished over the past century, both in number and distribution through loss of habitat, hunting and land clearance for farming; land degradation due to overgrazing is also an intensive. Furthermore, even many endemic wild species occur within the country some of which inhabit only very small areas [10].

Species wise, 926 species of birds were identified and listed in Ethiopia so far, of which 21 species are endemic [10]. Studies of the total species number of birds in Ethiopia has been largely based on morphological data, therefore, this numbering is probably underestimated as compared to the world wide species of birds, which is reported so far 9159 species of birds morphologically, and the current taxonomy has revised based on molecular data which yields 18,043 species of birds [3]. Even though, underestimation is in consideration, for this large species of birds, there are different contributors or important bird site areas in Ethiopia, 73 areas are identified as important bird areas, among these, 30 of these sites comprised wetlands [20].

The study of population size or considerable abundance of birds is widely used in bird conservation [5], since they are important indicators of the impact of habitat loss. Estimating abundance of bird species enables to measure changes in population size and additionally to judge the quality and seasonal prediction of a given area. Occurrence and distribution of bird species correlate with vegetation structure and of course with elevation, which affects the condition of the physical environment [18]. For the reason that the kinds and quantities of resources available for breeding and foraging activities, the composition and structure of bird communities may change along elevational gradients. Several studies on birds have assessed the typical importance of microhabitats and vegetation composition [2], elevational changes, afforestation and deforestation conditions for occurrence and their abundance. 
Vegetation variety is the factor for the diversity of birds and which has been reported in several literatures. For example, Soka et al. [17] and Seoane et al. [16] revealed that the presence of varieties of microhabitats which provide the niche for different species of birds and at the same time resulted in a high number of bird species in terrestrial habitats.

Seasonal and vegetation changes lead to show the patterns of a particular species of birds since the survival of some species is positively associated with adaption and habitat changes. Similarly, Bibi and Ali [4] clearly noted that ecosystem stability depends on species richness and composition. However, it has become clear that avian diversity can be affected by multiple factors, including, patch and landscape, regional patterns which, fully accounts for species diversity [6, 8, 15]. Likely, Develey and Peres [7] have clearly demonstrated that species richness of birds varies with the seasonal variations. Different studies, however, have investigated a positive correlation between rainfalls, incidence of fruit and insect availability has resulted in diversified species of birds [7, 13, 16].

Furthermore, it is true that seasonal conditions demands on animal species in general and birds in particular, which must respond with behavioral and physiological adaptations, including shifting resource use or migration to other geographical areas with tolerable conditions [21, 13]. This can be evidenced with a bird species, Agapornis taranta commonly called black -winged lovebird, which only be observed during the rainy seasons and not seen during the dry seasons in our current study area.

Therefore, remedial actions like effective restoration and biodiversity conservation efforts are suggested as basic approaches for the stable survival of birds both in species composition and diversity. As our study site has been established recently and a forested area, conducting the avian survey is very critical to keep the management improvements of the Block.

\section{Materials and Methods}

\subsection{The Study Area}

The study was carried out in Dilfekar Block, Arsi Mountains National Park (Figure 1). The Block is found in Dilfekar Kebele in Dodota Sire district, adjacent to Dera town, the center of the District, Eastern Shoa Zone. It is situated $125 \mathrm{~km}$ south of Addis Ababa, and $55 \mathrm{~km}$ north of Asella, the Zonal capital. The study locality is only $25 \mathrm{~km}$ and $15 \mathrm{~km}$ from Adama town and Sodere Resort center respectively. Dilfekar is one of the four Blocks (ChilaloGalama, Kaka, Hoqolo and Dilfekar) of the Arsi Mountains National Park. Total area coverage is 1,341 ha.

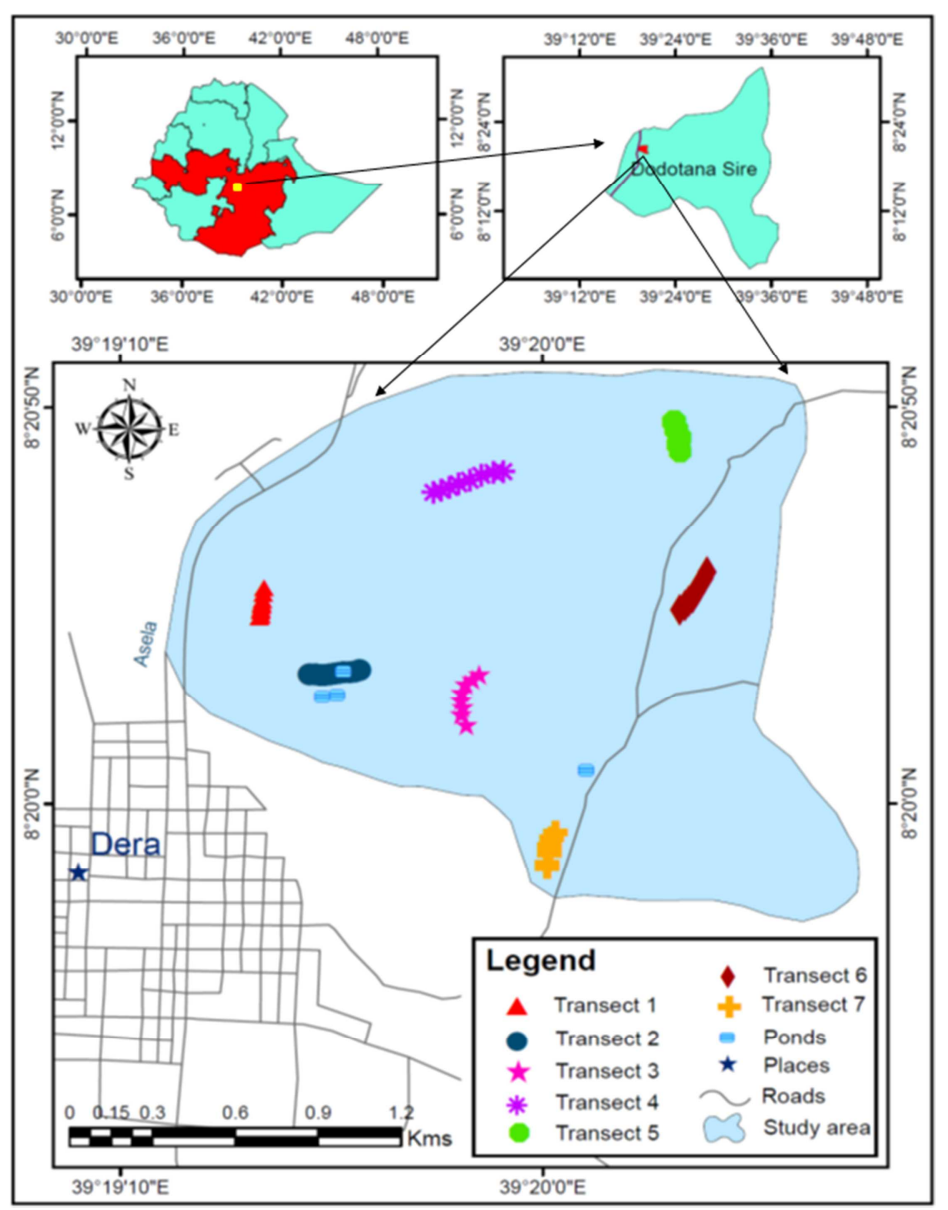

Figure 1. Map of the study area. 
Since there is no meteorological record of the study area, the data was taken from the Ethiopian National Meteorology Agency (2000-2015) of Sodere, which is the adjacent site at northeastern part of the Block. Thus, the mean monthly temperature ranges from $11.2^{\circ} \mathrm{C}$ to $35.6^{\circ} \mathrm{C}$. The average rainfall varies from $7.1 \mathrm{~mm}$ in February to $179.6 \mathrm{~mm}$ in July.

\subsection{Sampling Design}

First, the topography of the study area was assessed before sampling site selection. Then line transect (L) of $100 \mathrm{~m}$ in length and $15 \mathrm{~m}$ width was placed on the representative microhabitats within locally named sites, Ketema Kilil (L1 and L2), Valley area (L3), Fichiso (L4), Garadima (L5), Dire Kiltu (L6) and Dilfekar (L7).

\subsection{Data Analysis}

The species richness, diversity and similarity were computed by using a different formula to estimate diversity and similarity between different transect lines. The ShannonWeiner Diversity Index was used to estimate the diversity of the terrestrial avian groups in the study area using the formula $\left(\mathrm{H}^{\prime}=-\Sigma \mathrm{Pi} \mathrm{Ln}\right.$ pi), where, $\mathrm{H}^{\prime}=$ species diversity, $\mathrm{Pi}=$ the proportion of species of the total sample belonging to its avian group, $\mathrm{Ln}=$ the natural logarithm. To predict whether there is complete evenness or no evenness among sampling transects, species evenness of avian was also calculated by using the formula $\mathrm{E}=\mathrm{H}^{\prime} / \mathrm{H}^{\prime} \max$. One way ANOVA was used and compared with $0.05 \mathrm{P}$ value.

\section{Results and Discussion}

In this study, a total of 99 species of birds under the category of 35 families were recorded (Appendix 1). Concerning the number of species recorded under each family, 12 families contain the least number with each has a single species. Contrarily, the highest number of species recorded per a family was 8 , under Ploceidae. From the time perspective of on-site data collection, early morning surveys were resulted more species of birds compared with the afternoon's. The higher number (81) of avian species was recorded during the wet season compared with the dry season (73). The higher number of species in the wet season could be due to the presence of green vegetation which provides sufficient food in the form of flower nectars, insects and others. Contrarily, many reasons, including the migration of birds and vegetation changes might have attributed the dry season with less numbers of species. However, no statistical significant difference in number of species between the seasons $\left(\chi^{2}=0.4, \mathrm{df}=1, \mathrm{p}>0.05\right)$.

Only Agapornis taranta, an endemic species in Ethiopia and Eritrea, was observed during the wet season of the study periods. This species was recorded only in line transect 6, which might be with the positive association of the presence of various plants in the microhabitat. Milvus migrans and Aquila rapax were commonly recorded from line transect 1 .
This might be the founding of domestic wastes and cattle ranches at the proximate of the line transect. Similarly, Gatesire et al. [9] reported that some species of birds like Corvus albus was abundantly found along with human dominated landscapes.

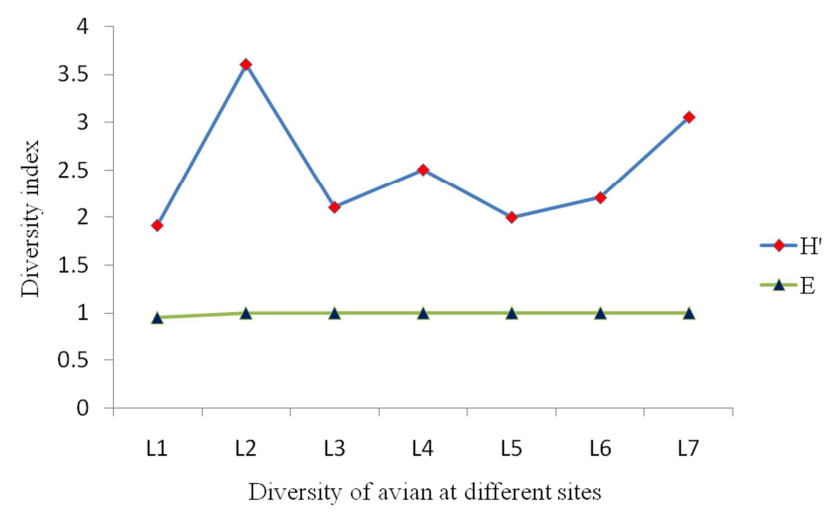

Figure 2. Diversity and evenness proportions of avian species in different sites: $H^{\prime}$ indicate the Shannon diversity index and $E=$ Evenness index.

The highest and the lowest values of the Shannon diversity index was observed in Transect $2\left(\mathrm{H}^{\prime}=3.6\right)$ and Transect 1 $\left(H^{\prime}=1\right.$. 91) respectively (Figure 2). The highest Shannon diversity index in Transect 2 indicates the species richness and relative abundance in the microhabitat which could be resulted from the favorability of the habitat. Transect 2 lays seemingly on the favorable environments with the relatively dense tree coverage, water pond and less human movements. There are different reports in agreement with the current study, avian diversity varies along with habitat variation [11]; avian species richness is high in the pond area [14]. The Shannon diversity index is directly related to the number of individuals per species [17] and the large mass of a species of birds could be seen around the site during the study period. As Albuquerque et al. [1], the lowest diversity in Transect 1 might be related to human pressures as the transect found around at the Block's interface site with the Dera town. Different recreational activities like chewing khat by the youths from the nearby arena and the livestock grazing was observed during the study time, which could possibly be speculated for the less richness of birds. However, diversity of avian groups among the transects as per the Shannon diversity index value was not statistically significant $\left(\chi^{2}==1.4, \mathrm{df}=6, \mathrm{p}>0.05\right)$.

The Evenness index value of all transects in both wet and dry seasons was 1 except on Transect 1 during the dry season, which was 0.9. The possible reason for this value almost all are a unit is, the macro level home range of the Block is narrow.

As it is shown on Figure 3, transect line 2 (L2) was found to have the most abundant bird species where a lot of nests were observed. Of the seven transects, transect 3 and 5 have resulted in almost similar less abundance of bird species. This might be due to the poor microhabitats with the scarcity of water and food items, as the Transect 3 is found in the 
drier exposed open gorge and the Transect 5 found at the peak altitude of the Block, locally called 'Gaaraa Dimaa' which means a 'Red Mountain', where the grassland coverage with a scattered shrubs was observed.

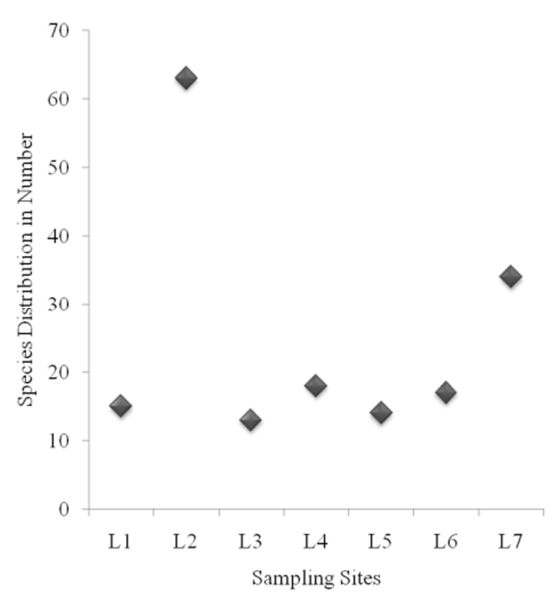

Figure 3. Abundance of different species of birds at the sampling Transects.

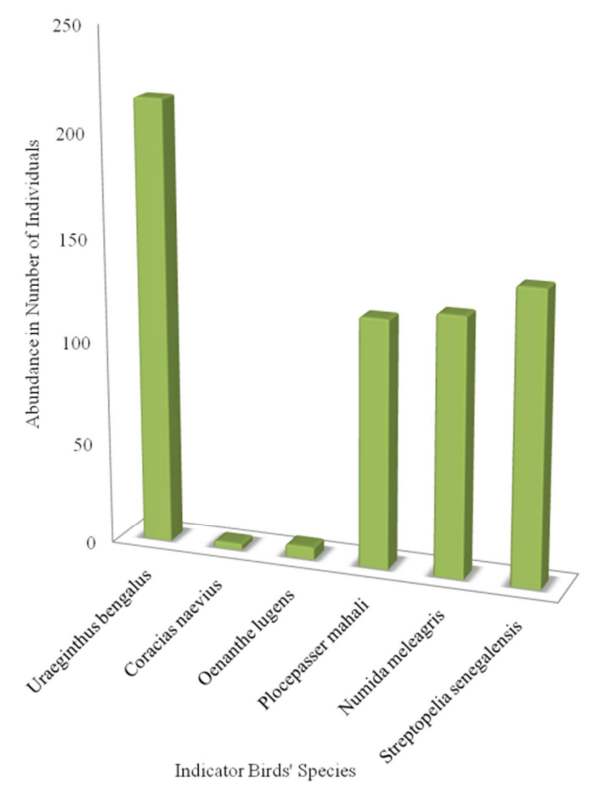

Figure 4. Some indicator species of birds to study the habitat quality of the area.

The selected species (Figure 4) were considered as indicators to understand the quality of the microhabitats and the Block at a large. Accordingly, abundantly recorded avian species were Uraeginthus bengalus while the least was Coracias naevius. Uraeginthus bengalus was commonly distributed in all sampling Transects, where the highest was in Transect $2(32 \%)$ and the least was in Transect $5(4.2 \%)$. The Coracias naevius species has a distinctive behavior to flee when it saws someone around or hears a sound which might be the reason for its least percentage record. The next rare species found in the study area were Oenanthe lugens which was seen only in Transect 3 and Transect 5. This species seems an "engineer" which builds underground microhabitats by digging the soil in the valley areas which could serve as a home for itself and other organisms.

There was a significant difference in individual number of Uraeginthus bengalus, Streptopelia senegalensis, Numida meleagris and Plocepasser mahali among transects $\left(\chi^{2}=82.68\right.$, $\mathrm{df}=6, \mathrm{p}<0.05, \chi^{2}=46.5, \mathrm{df}=6, \mathrm{p}<0.05, \chi^{2}=193, \mathrm{df}=6, \mathrm{p}<0.05$ and $\chi^{2}=45.5, \mathrm{df}=6, \mathrm{p}<0.05$, respectively). However, the individual number the two rarest species, Coracias naevius and Oenanthe lugens, were not statistically significant among transect the $\left(\chi^{2}=9.24, \mathrm{df}=6, \mathrm{p}<0.05\right.$ and $\chi^{2}=8.7, \mathrm{df}=6, \mathrm{p}<0.05$, respectively).

This study has shown a potential avifaunal diversity with both species richness and relative abundance in the Dilifekar Block. Moreover, this study has presented baseline information of the study area for the future ecological monitoring of the birds and their habitat status. Finally, spatial-temporal study, habitat rehabilitation and restoration actions to secure availability of food resources and ensuring water access throughout the microhabitats for the avian species are recommended.

\section{Conflict of Interest}

The authors declared no potential conflicts of interest with respect to this research article.

\section{Acknowledgements}

The authors are highly thankful to Adama Science and Technology University for funding for this project. We are also highly obliged and grateful to Oromia Forest and Wildlife Enterprise and Arsi Mountains National Park, Dilifekar Block staffs for their assistance and permission for the field work.

\section{Appendix}

Appendix 1. The total avian taxonomy in Dilfekar Block, Arsi Mountains National Park, Ethiopia.

\begin{tabular}{lll}
\hline Family & Species & Common name \\
\hline \multirow{2}{*}{ Columbidae } & Streptopelia senegalensis & Laughing Dove \\
& Streptopelia capicola & Ring-necked Dove \\
& Red-eyed Dove & Namaqua Dove \\
& Streptopelia semitorquata & Speckled Pigeon \\
& Columba guinea & Northern Red-billed Hornbill \\
Bucerotidae & Tockus erythrorhynchus & Hemprich's Hornbill \\
& Tockus hemprichii & African Gray Hornbill \\
\hline
\end{tabular}




\begin{tabular}{|c|c|c|}
\hline Family & Species & Common name \\
\hline \multirow{3}{*}{ Bucerotidae } & Tockus erythrorhynchus & Northern Red-billed Hornbill \\
\hline & Tockus hemprichii & Hemprich's Hornbill \\
\hline & Tockus nasutus & African Gray Hornbill \\
\hline \multirow{4}{*}{ Meropidae } & Merops bulocki & Red-throated Bee-eater \\
\hline & Merops pusillus & Little Bee-eater \\
\hline & Merops persicus & Blue-cheeked Bee-eater \\
\hline & Merops orientalis & Green Bee-eater \\
\hline \multirow[t]{2}{*}{ Caprimulgidae } & Caprimulgus longipennis & Standard-winged Nightjar \\
\hline & Tchagra senegalus & Black-crowned Tchagra \\
\hline \multirow{3}{*}{ Malaconotidae } & Laniarius ruficeps & Red-naped Bushsh rike \\
\hline & Nilaus afer & Brubru \\
\hline & Tchagra minutes & Marsh Tchagra \\
\hline Dicruridae & Dicrurus adsimilis & Fork-tailed Drongo \\
\hline Monarchidae & Terpsiphone viridis & African Paradise-Flycatcher \\
\hline Pycnonotidae & Pycnonotus barbatus & Common Bulbul \\
\hline \multirow[t]{3}{*}{ Phylloscopidae } & Phylloscopus sibilatrix & Wood Warbler \\
\hline & Cisticola erythrops & Red-faced Cisticola \\
\hline & Cisticola cantans & Singing Cisticola \\
\hline \multirow[t]{5}{*}{ Cisticolidae } & Cisticola chiniana & Rattling Cisticola \\
\hline & Cisticola cinereolus & Ashy Cisticola \\
\hline & Cisticola nana & Tiny Cisticola \\
\hline & Cossypha natalensis & Red-capped Robin-Chat \\
\hline & Oenanthe lugens & Mourning Wheatear \\
\hline \multirow{4}{*}{ Muscicapidae } & Oenanthe lugubris & Abyssinian Wheatear \\
\hline & Oenanthe pleschanka & Pied Wheatear \\
\hline & Oenanthe isabellina & Isabelline Wheatear \\
\hline & Lamprotornis chalybaeus & Greater Blue-eared Glossy-Starling \\
\hline \multirow{3}{*}{ Sturnidae } & Lamprotornis chloropterus & Lesser Blue-eared Glossy-Starling \\
\hline & Lamprotornis purpuroptera & Rueppell's Glossy-Starling \\
\hline & Lamprotornis superbus & Superb Starling \\
\hline \multirow{4}{*}{ Nectariniidae } & Nectarinia kilimensis & Bronze Sunbird \\
\hline & Cinnyris habessinicus & Shining Sunbird \\
\hline & Cinnyris venustus & Variable Sunbird \\
\hline & Cinnyris pulchellus & Beautiful Sunbird \\
\hline \multirow{2}{*}{ Passeridae } & Passer swainsonii & Swainson's Sparrow \\
\hline & Carpospiza brachydactyla & Pale Rock finch \\
\hline \multirow{8}{*}{ Ploceidae } & Plocepasser mahali & White-browed Sparrow-Weaver \\
\hline & Ploceus baglafecht & Baglafecht Weaver \\
\hline & Plocepasser superciliosus & Chestnut-crowned Sparrow-Weaver \\
\hline & Ploceus luteolus & Little Weaver \\
\hline & Anaplectes rubriceps & Red-headed Weaver \\
\hline & Ploceus bojeri & Golden Palm Weaver \\
\hline & Ploceus cucullatus & Village Weaver \\
\hline & Euplectes gierowii & Black Bishop \\
\hline \multirow{4}{*}{ Estrildidae } & Estrilda astrild & Common Waxbill \\
\hline & Uraeginthus bengalus & Red-cheeked Cordon blue \\
\hline & Lagonosticta senegala & Red-billed Fire finch \\
\hline & Lagonosticta rubricata & African Fire finch \\
\hline \multirow{2}{*}{ Viduidae } & Vidua macroura & Pin-tailed Whydah \\
\hline & Vidua chalybeata & Village Indigo bird \\
\hline \multirow{2}{*}{ Strigidae } & Bubo cinerascens & Grayish Eagle-Owl \\
\hline & Circaetus cinereus & Brown Snake-Eagle \\
\hline Accipitridae & Aquila rapax & Tawny Eagle \\
\hline & Melierax poliopterus & Eastern Chanting-Goshawk \\
\hline & Circus macrourus & Pallid Harrier \\
\hline & Milvus migrans & Black Kite \\
\hline Alcedinidae & Halcyon senegalensis & Woodland Kingfisher \\
\hline Upupidae & Upupa epops & African hoopoe \\
\hline Numididae & Numida meleagris & Helmeted Guinea fowl \\
\hline Sylviidae & Sylvia borin & Garden Warbler \\
\hline syivildae & Sylvia boehmi & Banded Warbler \\
\hline & Cercotrichas minor & African Scrub-Robin \\
\hline & Phoenicurus phoenicurus & Common Redstart \\
\hline Muscicapidae & Cercomela familiaris & Familiar Chat \\
\hline & Monticola rufocinereus & Little Rock-Thrush \\
\hline & Luscinia megarhynchos & Common Nightingale \\
\hline Motacillidae & Motacilla flava & Western Yellow Wagtail \\
\hline
\end{tabular}




\begin{tabular}{lll}
\hline Family & Species & Common name \\
\hline Emberizidae & Emberiza cineracea & Cinereous Bunting \\
& Serinus flavivertex & Yellow-crowned Canary \\
& Serinus leucopygius & White-rumped Seedeater \\
Fringillidae & Serinus citrinelloides & African Citril \\
& Serinus hypostictus & Southern Citril \\
& Serinus dorsostriatus & White-bellied Canary \\
& Serinus striolatus & Streaky Seedeater \\
Turdidae & Serinus reichardi & Reichard's Seedeater \\
Indicatoridae & Turdus pelios & African Thrush \\
& Prodotiscus zambesiae & Green-backed Honey guide \\
\hline
\end{tabular}

\section{References}

[1] Albuquerque, T. A., Benayas, M. R., Rodriguez, M. A. and Albuquerque, F. S. (2012). Geographic patterns of vertebrate diversity and identification of relevant areas for conservation in Europe. Animal Biodiversity and Conservation 35: 1-11.

[2] Anjos, L. D., Collins, C. D., Holt, R. D, Volpato, G. H., Mendonça, L. B., Lopes, E. V., Boçon, R. Bisheimer, M. V., Serafini, P. P., Carvalho, J. (2011). Bird species abundance occupancy patterns and sensitivity to forest fragmentation: Implications for conservation in the Brazilian Atlantic forest. Biological Conservation 144: 2213-2222.

[3] Barrowclough, G. F., Cracraft, J, Klicka J, Zink, R. M. (2016). How Many Kinds of Birds Are There and Why Does It Matter? PLOS ONE 11: 1-15.

[4] Bibi, F and Ali, Z (2013). Measurement of diversity indices of avian communities at Taunsa barrage wildlife sanctuary, Pakistan. The Journal of Animal \& Plant Sciences 23: 469474.

[5] Buckland, S. T., Marsden, S. J. and Green, R. E. (2008). Estimating bird abundance: making methods work. Bird Conservation International 18: 91-108.

[6] Cushman, S. A. and Mcgariga, K. (2003). Landscape-level patterns of avian diversity in the Oregon coast range. Ecological Monographs, 73 (2): 259-281.

[7] Develey, P. F. and Peres, C. A. (2000). Resource seasonality and the structure of mixed species bird flocks in a coastal Atlantic forest of southeastern Brazil. Journal of Tropical Ecology 16: 33-53.

[8] Dorp, D. V. and Opdam, P. F. M. (1987). Effects of patch size, isolation and regional abundance on forest bird communities. Landscape Ecology 1: 59-73.

[9] Gatesire, T; Nsamiana, D; Nyiramana, A; Seburange, J. L.; and Mirville, M. O. (2014). Bird diversity and distribution in relation to urban landscape types in Northern Rwanda. The Scientific World Journal 3: 1-12.

[10] Lepage, D., (2006). Avi-base -Birds Checklists of the WorldEthiopia. http://www.bsc-eco.org. Accessed on $5^{\text {th }}$ April, 2015.
[11] Melaku Tefera (2011). Wildlife in Ethiopia: endemic large mammals. World J. Zool. 6: 108-116.

[12] Mohan, D and Gaur, A. (2008). Avian diversity around Jajiwal Pond a natural wetland. Proceedings of Taal 2007: The $12^{\text {th }}$ World Lake Conference: 542-546.

[13] Morgan, W. T. W. (1973). East Africa. Longman, London, pp: 410.

[14] Nirmala, T. (2016). Food availability influences the seasonality of bird community in tropical forest, Western Ghats. International Journal of Current Research and Review (Int. J. Cur. Res. Rev) 8: 74-83.

[15] Ntongani, W. A. and Andrew, S. M. (2013). Bird species composition and diversity in habitats with different disturbance histories at Kilombero Wetland, Tanzania. Open Journal of Ecology 3: 482-488.

[16] Rompre, G., Robinson, W. D., Desrocers, A. and Angehr, G. (2007). Environmental correlates of avian diversity in lowland Panama rain forests. Journal of Biogeography.

[17] Seoane, J., Villen-Pereze, S. and Carrascal, L. M. (2013). Environmental determinants of seasonal changes in bird diversity of Mediterranean oakwoods. Ecological Research 1: $1-13$.

[18] Soka, G. E. Munishi, P. K. T. and Thomas, M. B. (2013). Species diversity and abundance of Avifauna in and around Hombolo Wetland in Central Tanzania. International Journal of Biodiversity 5: 782-790.

[19] Waterhouse, F. L., Monica H. Mather, M. H. and Seip, D. (2002). Distribution and abundance of birds relative to elevation and biogeoclimatic zones in coastal old-growth forests in southern British Columbia. B. C. Journal of Ecosystems and Management 2: 1-13.

[20] Yalden, D. and M. Largen, (1992). Endemic Mammals of Ethiopia. Mammal Review 22: 115-150.

[21] Young, J. (2012). Ethiopian Protected Areas, A 'Snapshot'. A reference guide for future strategic planning and project funding. Pp: 1-46. 